\title{
Landsat TM and ETM+ derived snowline altitudes in the Cordillera Huayhuash and Cordillera Raura, Peru, 1986-2005
}

\author{
E. M. McFadden ${ }^{1, *, * *}$, J. Ramage ${ }^{1}$, and D. T. Rodbell ${ }^{2}$ \\ ${ }^{1}$ Earth and Environmental Sciences, Lehigh University, 1 West Packer Ave., Bethlehem, PA 18015, USA \\ ${ }^{2}$ Geology Department, Union College, Schenectady, NY 12308, USA \\ *now at: Byrd Polar Research Center, The Ohio State University, 1090 Carmack Road, Columbus, OH 43210, USA \\ ** now at: School of Earth Sciences, The Ohio State University, 275 Mendenhall Laboratory, 125 S. Oval Mall, \\ Columbus, OH 43210, USA
}

Received: 13 August 2010 - Published in The Cryosphere Discuss.: 6 October 2010

Revised: 10 March 2011 - Accepted: 4 May 2011 - Published: 23 May 2011

\begin{abstract}
The Cordilleras Huayhuash and Raura are remote glacierized ranges in the Andes Mountains of Peru. A robust assessment of modern glacier change is important for understanding how regional change affects Andean communities, and for placing paleo-glaciers in a context relative to modern glaciation and climate. Snowline altitudes (SLAs) derived from satellite imagery are used as a proxy for modern (1986-2005) local climate change in a key transition zone in the Andes.

Clear sky, dry season Landsat Thematic Mapper (TM) and Enhanced Thematic Mapper (ETM+) satellite images from 1986-2005 were used to identify snowline positions, and their altitude ranges were extracted from an Advanced Spaceborne Thermal Emission and Reflection Radiometer (ASTER) digital elevation model (DEM). Based on satellite records from 31 glaciers, average snowline altitudes (SLAs), an approximation for the equilibrium line altitude (ELA), for the Cordillera Huayhuash (13 glaciers) and Cordillera Raura (18 glaciers) from 1986-2005 were 5051 m a.s.l. from 19862005 and 5006 m a.s.l. from 1986-2002, respectively. During the same time period, the Cordillera Huayhuash SLA experienced no significant change while the Cordillera Raura SLA rose significantly from $4947 \mathrm{~m}$ a.s.l. to $5044 \mathrm{~m}$ a.s.l.
\end{abstract}

\section{Introduction}

The Cordilleras Huayhuash $\left(10^{\circ} 15^{\prime} \mathrm{S}, 76^{\circ} 55^{\prime} \mathrm{W}\right)$ and Raura $\left(10^{\circ} 27^{\prime} \mathrm{S}, 76^{\circ} 46^{\prime} \mathrm{W}\right)$ are tropical glacierized ranges located in a remote region of the Andes Mountains in central Peru (Fig. 1). The Cordillera Huayhuash is southeast of the larger

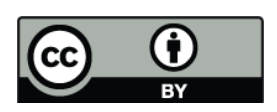

Correspondence to: J. Ramage (ramage@lehigh.edu) and better-known Cordillera Blanca, and has 117 glaciers covering $\sim 85 \mathrm{~km}^{2}$ (Morales Arnao, 2001). Peaks are typically over $6000 \mathrm{~m}$ a.s.l., with the highest peak recorded at 6617 m a.s.l. (Nevado Yerupajá). The Cordillera Raura, located to the southeast of the Cordillera Huayhuash, has a slightly smaller $\left(55 \mathrm{~km}^{2}\right)$ glacier area (Morales Arnao, 2001). The close proximity of the two ranges allows for a reasonable comparison of snowline altitude (SLA) change and assessment of potential regional causes of SLA change. The climate on the eastern side of the Andes is largely affected by orographic uplift and condensation of moist tropical air from the Amazon basin creating an east-west precipitation decrease (Kaser and Osmaston, 2002). Modern Tropical Rainfall Mapping Mission- (TRMM) derived precipitation highlighting the east to west gradients are shown effectively at a $>5 \mathrm{~km}$ scale in Bookhagen and Strecker (2008).

In this study, remote sensing was employed to measure and map modern snowlines (snow-ice boundaries), as an approximation of the equilibrium line altitude (ELA). Snowlines at the end of the melt season map the minimum elevation where glacier ice is continuously covered by snow. Snowline altitudes (SLAs) serve as a good proxy for ELAs and therefore for mass balance and climate reconstructions. SLAs in this tropical environment generally track ELAs although they could be slightly lower than the ELAs (Andrews, 1975); however, snowlines mapped during the dry season with minimal snow cover should reasonably approximate the ELA position in the absence of superimposed ice (Klein and Isacks, 1998). Remote sensing allowed spatially consistent temporal reconstruction of SLAs over the past twenty years in this high relief region. In order to accurately measure SLAs in the Cordilleras Huayhuash and Raura, satellite imagery was analyzed based on the unique reflectance characteristics of different materials at visible and near infrared wavelengths.

Published by Copernicus Publications on behalf of the European Geosciences Union. 


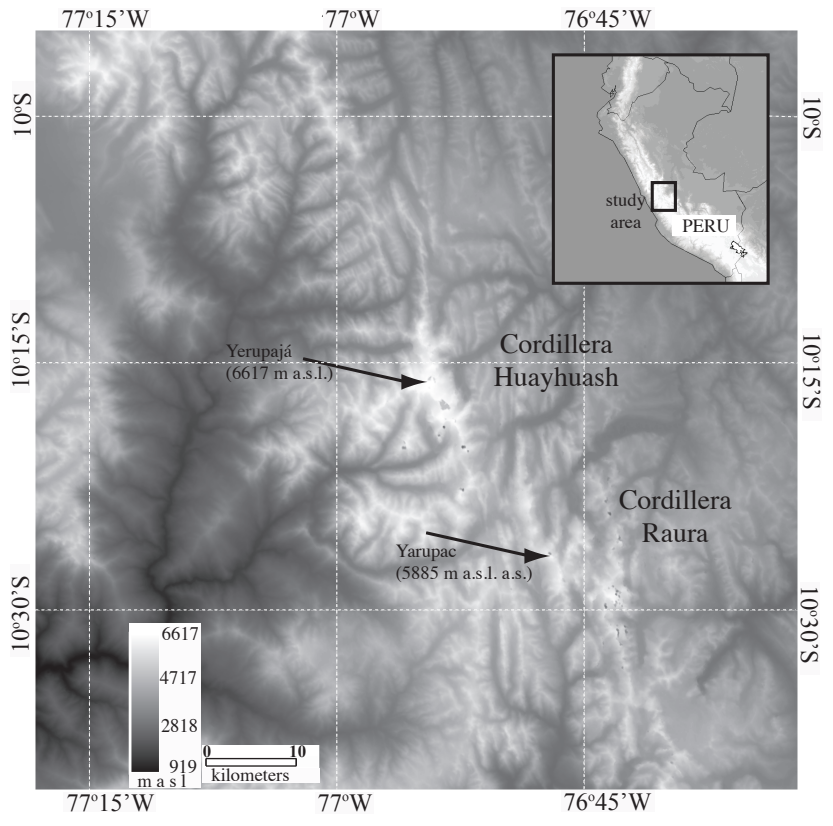

Fig. 1. The Advanced Spaceborne Thermal Emission and Reflection Radiometer (ASTER) DEM of the Cordilleras Huayhuash and Raura was used for SLA measurements due to its high, uniform resolution (15-m). The inset map of Peru shows the general location of the cordilleras.

Although both snowlines and terminus positions could be measured using remote sensing, snowlines and thus SLAs, were monitored here because they respond directly and annually to local meteorological influences in a region where meteorological data are scarce yet significant. Modern SLA variability is important on a regional scale, as mountain glaciers are important sources of water for agriculture, hydroelectric power, and consumption, particularly during the dry season (Kaser et al., 2003; Mark, 2005; Bradley et al., 2006), throughout the Peruvian coastal desert. Our data include new spatial and temporal SLA variations monitored with satellite imagery, which may be used as a climate proxy in this remote region.

\section{Methods}

\subsection{Satellite image selection}

Landsat 5 Thematic Mapper (TM) and Landsat 7 Enhanced Thematic Mapper (ETM+) data with 30-m resolution were used for snowline observations. Landsat 5 TM data were compiled for 1986, 1989, 1991, 1996, and 1997 and Landsat 7 ETM+ data were used for 1999, 2002, 2004, and 2005. Dates and sources for each image are in Table 1.
Images were preferentially selected during the dry season to maximize the probability of extracting snowlines at minimum snow-cover. One December (wet season) image was included from 1989 to fill the gap in the late 1980s, and it displays the lowest snowlines of any measured. In this region of Peru, the dry season begins during May and gradually ends through September with typically only $20 \%$ of the total annual precipitation recorded over this time (Schwerdtfeger, 1976). Seven of nine images were taken from June through August to best approximate minimum snow cover (Table 1). Although the images are not from the same date, they are the best Landsat images available for SLA approximation by snowline measurement. Images with signs of recent high elevation snowfall were not included because they represent a short-term adjustment rather than the dry season snowline. Absence of cloud cover was also considered because clouds obscure glaciers and create shadows that complicate the classification process. The high relief of the ranges also means that many small glaciers could not be included due to the presence of shadows. These constraints limited snowline measurement to 9 years over a twenty year period on 31 glaciers in the Cordilleras Huayhuash and Raura.

Glacierized valleys were identified using the name of the lake in the closest valley (Fig. 2; A-Z and AA-EE). Since cocha means lake in Quechua, most valleys contain cocha in part of their name. This naming scheme was used whenever possible for glaciers to minimize confusion. If a lake was not located within a reasonable distance from the glacial terminus, then the name of the nearest peak was used.

\subsection{Image calibration}

Landsat 5 TM data used for SLA measurements were calibrated to radiance and then planetary reflectance as a method of standardization. Similar calibration techniques were employed on Bolivian Landsat TM images by Klein and Isacks (1998) to improve the quality of snow-ice differentiation. The procedures for calibration employed in this study were taken from Chander and Markham (2003). Once calibrated for radiance and reflectance, images had pixel values ranging from 0-1.0, representing planetary reflectance as a ratio. The equations used for all calibrations are found below (Eqs. 1 and 2). Data from Tables 1 and 2 were used in these calculations.

The following procedures were used to calibrate images according to the effects of different solar angles and irradiance values between bands. To calibrate the images, metadata were provided by the Global Land Cover Facility (GLCF) at the University of Maryland, or by the United States Geological Society, EROS Data Center (EDC) (Table 1).

Radiance was calculated as:

$L_{\lambda}=\left[\left(L_{\max }-L_{\min }\right) D N_{\max }^{-1}\right] \cdot D N+L_{\min }$ 
Table 1. Landsat 5 and Landsat 7 data were used for SLA measurements. Data were purchased from the United States Geological Survey, Eros Data Center (USGS/EDC) or acquired from the Global Land Cover Facility (GLCF) at the University of Maryland. Metadata was extracted from both sources in order to form complete data sets. Values for $d$ are not provided for the ETM+ data because we did not process it. Scan Line Corrector failure for ETM+ images reduced the number of glaciers that could be assessed, but several glaciers were clearly imaged and the data were used for the study.

\begin{tabular}{lllcc}
\hline Date & Sensor & Source & $\begin{array}{c}\text { Resolution } \\
\text { (meters) }\end{array}$ & $\begin{array}{c}d \\
\text { (astronomical units) }\end{array}$ \\
\hline 22 June 1986 & Landsat 5 TM & USGS/EDC & 30 & 1.0163 \\
30 December 1989 & Landsat 5 TM & GLCF & 30 & 0.9833 \\
15 September 1991 & Landsat 5 TM & GLCF & 30 & 1.0057 \\
24 June 1996 & Landsat 5 TM & USGS/EDC & 30 & 1.0164 \\
27 June 1997 & Landsat 5 TM & USGS/EDC & 30 & 1.0165 \\
5 August 1999 & Landsat 7 ETM+ & USGS/EDC & 30 & N/A \\
17 June 2002 & Landsat 7 ETM+ & USGS/EDC & 30 & N/A \\
6 June 2004 & Landsat 7 ETM+ & USGS/EDC & 30 & N/A \\
11 July 2005 & Landsat 7 ETM+ & USGS/EDC & 30 & N/A \\
\hline
\end{tabular}

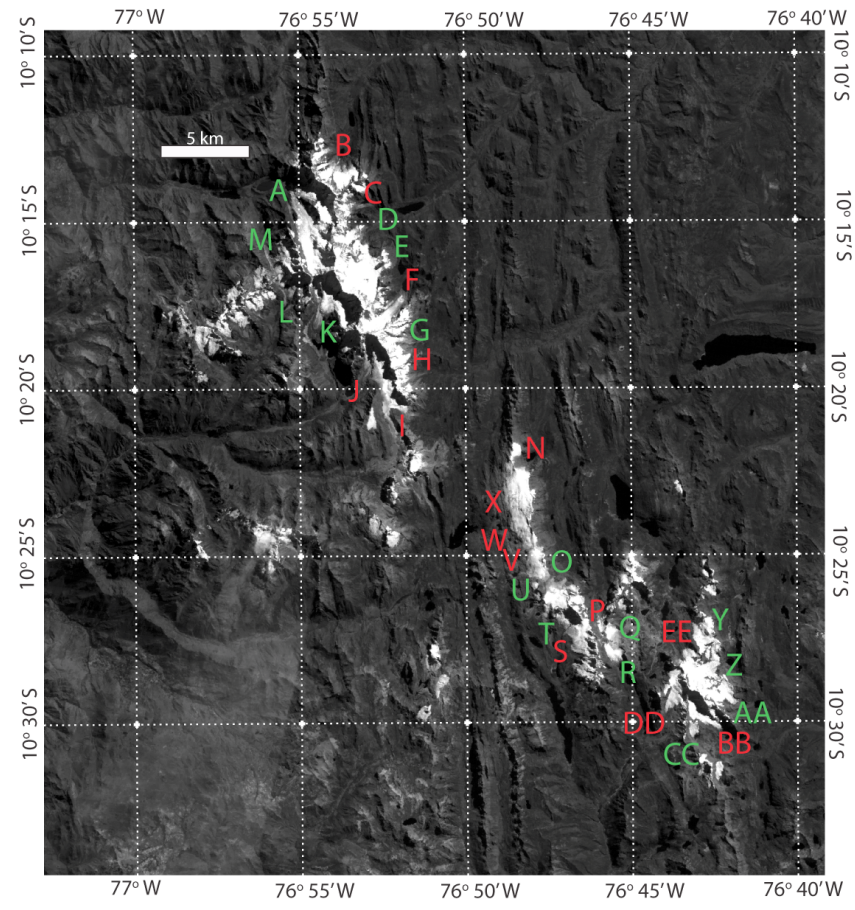

Fig. 2. Locations of glaciers discussed in the paper. Labels correspond to glaciers in Tables 3-5. Glaciers are labeled as follows: Jahuacocha (A), Mitococha (B), Chaclan (C), Carhuacocha (D), Gangrajanca (E), Quesillococha (F), Azulcocha (G), Carnicero (H), Barrosacocha (I), Jurau (J), Sarapococha (K), Caramarca (L), Rasac (M), Luychos (N), Huascacocha (O), Jaico (P), Niñococha (Q), Putusay (R), Checchi (S), Yuracocha (T), Agopampa (U), Viconga (V). Aguascocha (W), Carcamachay (X), Caballeros (Y), Mancaneota (Z), Pichuycocha (AA), Santa Rosa (BB), Condorsenja (CC), Yanco (DD), Caballococha (EE). Green (red) labels indicate glaciers with SLAs that are higher (lower) than the mean SLAs for the range.
Table 2. Band-specific data for $L_{\min }$ and $L_{\max }$ provided in this table were for spectral radiance calibration for all Landsat 5 data using the calibration technique in Eq. (1). Band-specific data for solar exoatmospheric irradiance $(S)$ were used in Eq. (2) to calibrate Landsat 5 data.

\begin{tabular}{cclc}
\hline Band & $L_{\min }$ & $L_{\max }$ & $S\left[\mathrm{~W}\left(\mathrm{~m}^{-2} \mu \mathrm{m}\right)\right]$ \\
\hline 1 & -1.52 & 152.1 & 1957 \\
2 & -2.84 & 296.81 & 1826 \\
3 & -1.17 & 204.3 & 1554 \\
4 & -1.51 & 206.2 & 1036 \\
5 & -0.37 & 27.19 & 215 \\
7 & -0.15 & 14.38 & 80.67 \\
\hline
\end{tabular}

The variables were defined by:

$L_{\lambda}=$ spectral radiance in $\mathrm{Wm}^{-2} \mathrm{sr}^{-1} \mu \mathrm{m}^{-1}$

$L_{\min }=$ spectral radiance where $D N=0$; (Table 2)

$L_{\max }=$ spectral radiance where $D N=255$; (Table 2)

$D N=$ the value of each wavelength band $(1,2,3,4,5,7)$

$D N_{\max }=$ maximum value for each band (255).

Bands were corrected individually to account for unique $D N_{\max }$ values and the wavelength specific data found in Table 2. Values from Table 2 can be used for Landsat 5 TM images taken between 1 March 1984 and 4 May 2003 (Chander and Markham, 2003).

Equation (2) was used in conjunction with the radiance images to create an image directly comparable to pre-calibrated Landsat 7 ETM+ images.

Planetary reflectance was calculated from:

$\rho_{\mathrm{P}}=\pi L_{\lambda} d^{2} S^{-1} \mu^{-1}$ 
where,

$\rho_{\mathrm{P}}=$ wavelength-specific planetary reflectance

(dimensionless)

$d=$ Earth-Sun distance (astronomical units) see Table 1

for values

$S=$ band-specific solar exoatmospheric irradiance

$\left(\mathrm{Wm}^{-2} \mu \mathrm{m}^{-1}\right)$

$\mu=$ cosine of the solar zenith angle.

Earth-Sun distances were obtained based on the day of year when each image was taken. The solar zenith angle (SZA) is $\pi / 2$ - solar elevation (radians). This process eliminates the effects of the changing position of the sun between images. Once all variables were defined, each band was calibrated to planetary reflectance $\left(\rho_{\mathrm{p}}\right)$ using the data for solar exoatmospheric irradiance $(S)$ from Table 2. Deep shadows were used to remove atmospheric effects.

\subsection{Geographic registration}

After completing calibration, the images were geographically registered to the coordinate system from the previously georeferenced 1997 ETM+ image. The coordinate system (UTM 18S, WGS 84 datum) from the 1997 image was selected as the base because the image displays the largest glaciated area including the Cordilleras Blanca, Huayhuash, and Raura. A large number ( $>80$ ) of ground control points (GCPs) distributed throughout each image were selected for georeferencing purposes. GCPs were focused around, but did not include, glacial margins due to their annual variability. All other images were georeferenced using GCPs and registered to the 1997 image. Some coordinate offsets of $\pm 140 \mathrm{~m}$ (5 pixels) magnitude were present in several registered images but the offsets were confined to the highest peaks where distortion is expected as these images were registered, not orthorectified. There was little distortion in the SLA zones.

\subsection{Supervised classification}

We used supervised classification of each calibrated image to get the snow-ice boundary. This method was used rather than the standard TM 4/5 ratio method applied by De Angelis et al. (2007) because calibrated images had enough variability in the spectral values of various materials that some features were clearly misclassified. Each image was classified individually to prevent false classification of snow and ice due to overlapping pixel ranges. Training areas such as clear water, snow, ice, clouds, snow in shadow, recently exposed bedrock, weathered bedrock, wetlands, slopes with vegetation, and water containing glacial flour were defined on each image to incorporate various materials necessary for characterizing the image and distinguishing snow and ice. Training area size and material composition were distributed to minimize user bias and image variations. Each training area, composed of multiple individual regions, contained over one hundred pixels. Borderline pixels were excluded from training area differentiation to prevent overlapping values and false classification. Although snow and firn may have similar spectral properties, we believe our classification scheme properly distinguished snow from other spectrally-similar materials as a result of the exclusion of borderline pixels within training areas; however, we have no field data to support our method's ability to distinguish snow and firn and acknowledge that this may have contributed to an unknown, variable magnitude of error for each image's snowline delineation. Avalanche-fed glaciers were also avoided during training area classification due to ambiguous pixel coloration. Images were classified based on their training area pixel values in order to create an image with all materials distinguished by their spectral values rather than manual interpretation.

\subsection{DEM comparison and snowline elevation extraction}

Linear overlays representing snowlines were created following image classification. The snowlines were overlaid on two digital elevation models (DEMs) to extract SLAs. DEMs were from the Shuttle Radar Topography Mission (SRTM) and the Advanced Spaceborne Thermal Emission and Reflection Radiometer (ASTER). The SRTM and ASTER digital elevation models were compared using identifiable ground features (e.g. moraines) to determine their accuracy.

Near-global 3-arc second (90-m) DEM data from the SRTM mission (February 2000, Farr and Kobrick, 2000) was evaluated for snowline determination. Significant data gaps exist from shadow and layover in high relief areas due to the synthetic aperture radar geometry. Data gaps were patched with over-sampled GTOPO30 data with 30-arc second ( $\sim 1 \mathrm{~km}$ ) resolution (Bliss and Olsen, 1996). The patched resolution was still inadequate, as high resolution was necessary for SLA measurements in several patched areas. To improve the problem of extracting reliable elevations, the stereo capabilities of ASTER band 3N (nadir) and 3B (backward) allowed creation of a DEM with $15-\mathrm{m}$ spatial resolution using the ASTER DEM module for ENVI (Fig. 1). ASTER data were higher resolution, but peak elevations were inaccurate. Despite the coarse elevations provided by the lower resolution SRTM DEM, it was used with La Carta Nacional 1:100000 topographic map (Yanahuanca: Hoja $21-\mathrm{j}, 2002$ ) of Peru to determine the extent of the ASTER DEM limitations. Elevations were compared at multiple locations (>100), exposing a region of underestimated elevations above $5600 \mathrm{~m}$ on the ASTER DEM relative to the SRTM DEM and the topographic map. Because SLAs were below the inaccurate region, the ASTER DEM was considered the most accurate DEM for this purpose. Error analysis from the comparison between the two DEMs is beyond the scope of this paper. The ASTER DEM was reliable below $5600 \mathrm{~m}$ a.s.1. and less reliable at elevations greater than $5600 \mathrm{~m}$ a.s.1., with SLAs located below the distorted zone. 
Table 3. Mean and standard deviation values for SLAs on each glacier in the Cordillera Huayhuash extracted from a 2005 ASTER DEM. The mean SLA for the range, displayed in the bottom right, is the mean of the individual glacier means for each year. The standard deviation for the mean SLA is calculated as a population statistic as described in the text.

\begin{tabular}{|c|c|c|c|c|c|c|c|c|c|c|c|c|}
\hline \multicolumn{13}{|c|}{ Cordillera Huayhuash } \\
\hline & \multicolumn{2}{|c|}{ Jahuacocha (A) } & \multicolumn{2}{|c|}{ Mitococha (B) } & \multicolumn{2}{|c|}{ Chaclan (C) } & \multicolumn{2}{|c|}{ Carhuacocha (D) } & \multicolumn{2}{|c|}{ Gangrajanca (E) } & \multicolumn{2}{|c|}{ Quesillococha (F) } \\
\hline Year & $\begin{array}{l}\text { Mean } \\
(\mathrm{m})\end{array}$ & $\begin{array}{l}\text { Standard } \\
\text { Deviation } \\
\text { (m) }\end{array}$ & $\begin{array}{l}\text { Mean } \\
(\mathrm{m})\end{array}$ & $\begin{array}{l}\text { Standard } \\
\text { Deviation } \\
\text { (m) }\end{array}$ & $\begin{array}{l}\text { Mean } \\
(\mathrm{m})\end{array}$ & $\begin{array}{l}\text { Standard } \\
\text { Deviation } \\
\text { (m) }\end{array}$ & $\begin{array}{l}\text { Mean } \\
(\mathrm{m})\end{array}$ & $\begin{array}{l}\text { Standard } \\
\text { Deviation } \\
\text { (m) }\end{array}$ & $\begin{array}{l}\text { Mean } \\
(\mathrm{m})\end{array}$ & $\begin{array}{l}\text { Standard } \\
\text { Deviation } \\
\text { (m) }\end{array}$ & $\begin{array}{l}\text { Mean } \\
(\mathrm{m})\end{array}$ & $\begin{array}{l}\text { Standard } \\
\text { Deviation } \\
(\mathrm{m})\end{array}$ \\
\hline 1986 & 5272 & 117 & 5009 & 71 & 4998 & 57 & 5133 & 41 & 5160 & 18 & 4875 & 40 \\
\hline 1989 & 5124 & 94 & 5017 & 50 & 4927 & 57 & 5095 & 28 & 5118 & 30 & 4880 & 8 \\
\hline 1996 & 5297 & 138 & 4992 & 44 & 4917 & 33 & 5059 & 23 & 5120 & 38 & 4923 & 22 \\
\hline 1997 & 5200 & 100 & 4996 & 40 & 4947 & 49 & 5071 & 30 & 5110 & 26 & 4877 & 25 \\
\hline 1999 & 5237 & 137 & 5023 & 42 & 4938 & 53 & 5069 & 39 & 5110 & 43 & 4876 & 25 \\
\hline 2002 & 5271 & 128 & 5055 & 28 & 4931 & 87 & 5074 & 34 & NA & NA & 4979 & 32 \\
\hline 2004 & 5275 & 112 & NA & NA & NA & NA & 5092 & 40 & 5103 & 28 & 5008 & 23 \\
\hline 2005 & 5291 & 117 & 5071 & 29 & 4971 & 21 & 5112 & 31 & 5121 & 28 & 4991 & 40 \\
\hline \multirow[t]{2}{*}{ Mean } & 5246 & 48 & 5023 & 17 & 4947 & 21 & 5088 & 12 & 5120 & 12 & 4926 & 10 \\
\hline & \multicolumn{2}{|c|}{ Azulcocha (G) } & \multicolumn{2}{|c|}{ Carnicero (H) } & \multicolumn{2}{|c|}{ Barrosacocha (I) } & \multicolumn{2}{|c|}{ Jurau (J) } & \multicolumn{2}{|c|}{ Sarapococha (K) } & \multicolumn{2}{|c|}{ Mean SLA } \\
\hline Year & $\begin{array}{l}\text { Mean } \\
(\mathrm{m})\end{array}$ & $\begin{array}{l}\text { Standard } \\
\text { Deviation } \\
\text { (m) }\end{array}$ & $\begin{array}{l}\text { Mean } \\
(\mathrm{m})\end{array}$ & $\begin{array}{l}\text { Standard } \\
\text { Deviation } \\
\text { (m) }\end{array}$ & $\begin{array}{l}\text { Mean } \\
(\mathrm{m})\end{array}$ & $\begin{array}{l}\text { Standard } \\
\text { Deviation } \\
\text { (m) }\end{array}$ & $\begin{array}{l}\text { Mean } \\
(\mathrm{m})\end{array}$ & $\begin{array}{l}\text { Standard } \\
\text { Deviation } \\
\text { (m) }\end{array}$ & $\begin{array}{l}\text { Mean } \\
(\mathrm{m})\end{array}$ & $\begin{array}{l}\text { Standard } \\
\text { Deviation } \\
\text { (m) }\end{array}$ & $\begin{array}{l}\text { Mean } \\
(\mathrm{m})\end{array}$ & $\begin{array}{l}\text { Standard } \\
\text { Deviation } \\
\text { (m) }\end{array}$ \\
\hline 1986 & 5149 & 0 & 5030 & 71 & NA & NA & 4929 & 271 & NA & NA & 5062 & 36 \\
\hline 1989 & 5088 & 14 & 4992 & 34 & 5035 & 28 & 4938 & 194 & 5147 & 99 & 5033 & 23 \\
\hline 1996 & 5093 & 14 & NA & NA & 4992 & 25 & 4928 & 381 & 5074 & 86 & 5039 & 42 \\
\hline 1997 & 5094 & 36 & 5104 & 44 & 5011 & 18 & 4946 & 178 & 5107 & 94 & 5042 & 22 \\
\hline 1999 & 5023 & 6 & NA & NA & NA & NA & 4913 & 177 & 5118 & 108 & 5034 & 29 \\
\hline 2002 & 5002 & 41 & 5050 & 16 & 4920 & 18 & 4945 & 151 & 5140 & 109 & 5037 & 25 \\
\hline 2004 & NA & NA & 5087 & 10 & 5041 & 5 & 4908 & 295 & NA & NA & 5074 & 46 \\
\hline 2005 & 5109 & 27 & 5109 & 27 & 5038 & 25 & 4941 & 320 & 5193 & 92 & 5086 & 33 \\
\hline Mean & 5080 & 9 & 5062 & 16 & 5006 & 9 & 4931 & 91 & 5130 & 40 & 5051 & 11 \\
\hline
\end{tabular}

Snowlines were mapped for each of 31 glaciers for every year with useable imagery and overlaid onto the ASTER DEM to determine the altitude range of snowlines (Fig. 2, Tables 3 and 4). Snowlines were mapped at the lowest elevation with nearly-continuous snow cover across the entire glacier width, thus ignoring discontinuous patches of snow at lower elevations which may have been more influenced by local effects (i.e. crevasses, shadowing, etc.) than air temperature. ASTER DEM elevations were extracted from all cells intersecting the linear overlays, providing minimum, maximum, mean, and standard deviation values for the annual SLA on each glacier. Tables 3 and 4 contain the extracted mean and standard deviation for glacier SLAs in both cordilleras. It is important to note that data derived from the ASTER DEM do not account for changes in surface elevation throughout the time series, which were not quantified for these ranges. Additionally, SLA data from Caramarca (L) and Rasac (M) glaciers were excluded from Table 3 and the statistical results shown therein due to their limited time series ( 2 of $9 \mathrm{yr}$ ). Data from 1991 were excluded from Table 3 and data from 2005 were excluded from Table 4 because their limited spatial coverage prevented proper statistical analysis of snowlines obtained from the satellite imagery. Values discussed throughout the text are the means for individual glaciers or for the entire range, both of which may have upwards of $10 \mathrm{~s}$ of meters of uncertainty due to snow cover, differences in seasonality, surface elevation changes relative to the 2004 DEM, inaccuracies in the DEM, etc. Standard deviations presented here do not include these uncertainties, but instead, reflect the elevation range of individual glacier snowlines.

\section{Results}

Snowline altitudes (SLAs) were calculated for 31 glaciers: 13 glaciers in the Cordillera Huayhuash and 18 glaciers in the Cordillera Raura. In the Cordillera Huayhuash, individual glaciers' SLAs range from $4875 \pm 40 \mathrm{~m}$ a.s.l. (Quesillococha (F), 1986) to $5291 \pm 117 \mathrm{~m}$ a.s.l. (Jahuacocha (A), 2005), excluding snowline data from Caramarca (L) and Rasac (M) glaciers (Table 3). Individual glaciers in the Cordillera 
Table 4. Mean and standard deviation values for SLAs on each glacier in the Cordillera Raura extracted from a 2005 ASTER DEM. The mean SLA for the range, displayed in the bottom right, is the mean of the individual glacier means for each year. The standard deviation for the mean SLA is calculated as a population statistic as described in the text. Due to the Scan Line Corrector failure there was some image degradation that affected Cordillera Raura glaciers in particular.

\begin{tabular}{|c|c|c|c|c|c|c|c|c|c|c|c|c|c|c|}
\hline & \multicolumn{2}{|c|}{ Luychos (N) } & \multicolumn{2}{|c|}{ Huascacocha $(\mathrm{O})$} & \multicolumn{2}{|c|}{ Jaico (P) } & \multicolumn{2}{|c|}{ Niñococha (Q) } & \multicolumn{2}{|c|}{ Putusay (R ) } & \multicolumn{2}{|c|}{ Checchi (S) } & \multicolumn{2}{|c|}{ Yuracocha $(\mathrm{T})$} \\
\hline Year & $\begin{array}{l}\text { Mean } \\
(\mathrm{m})\end{array}$ & $\begin{array}{l}\text { Standard } \\
\text { Deviation } \\
(\mathrm{m})\end{array}$ & $\begin{array}{l}\text { Mean } \\
(\mathrm{m})\end{array}$ & $\begin{array}{l}\text { Standard } \\
\text { Deviation } \\
\text { (m) }\end{array}$ & $\begin{array}{l}\text { Mean } \\
(\mathrm{m})\end{array}$ & $\begin{array}{l}\text { Standard } \\
\text { Deviation } \\
\text { (m) }\end{array}$ & $\begin{array}{l}\text { Mean } \\
(\mathrm{m})\end{array}$ & $\begin{array}{l}\text { Standard } \\
\text { Deviation } \\
\text { (m) }\end{array}$ & $\begin{array}{l}\text { Mean } \\
(\mathrm{m})\end{array}$ & $\begin{array}{l}\text { Standard } \\
\text { Deviation } \\
(\mathrm{m})\end{array}$ & $\begin{array}{l}\text { Mean } \\
(\mathrm{m})\end{array}$ & $\begin{array}{l}\text { Standard } \\
\text { Deviation } \\
\text { (m) }\end{array}$ & $\begin{array}{l}\text { Mean } \\
(\mathrm{m})\end{array}$ & $\begin{array}{l}\text { Standard } \\
\text { Deviation } \\
\text { (m) }\end{array}$ \\
\hline 1986 & 4987 & 21 & 4958 & 36 & 4991 & 36 & 5043 & 22 & 5027 & 18 & 4834 & 23 & 4870 & 7 \\
\hline 1989 & 5019 & 36 & 4984 & 19 & 5014 & 68 & 5048 & 15 & 5076 & 34 & 5010 & 17 & 4873 & 4 \\
\hline 1997 & NA & NA & 5036 & 13 & 4983 & 62 & 5081 & 7 & 5069 & 30 & 4996 & 30 & 5083 & 37 \\
\hline 1999 & 5010 & 20 & 4959 & 8 & 4979 & 60 & 5065 & 13 & 5094 & 12 & 4989 & 27 & 5106 & 29 \\
\hline 2002 & 5004 & 24 & 4985 & 9 & 4994 & 60 & 5062 & 13 & 5093 & 18 & 5009 & 16 & 5107 & 30 \\
\hline \multirow[t]{2}{*}{ Mean } & 5005 & 13 & 4984 & 9 & 4992 & 26 & 5060 & 7 & 5072 & 11 & 4968 & 10 & 5008 & 11 \\
\hline & \multicolumn{2}{|c|}{ Agopampa (U) } & \multicolumn{2}{|c|}{ Viconga (V) } & \multicolumn{2}{|c|}{ Aguascocha (W) } & \multicolumn{2}{|c|}{ Carcamachay (X) } & \multicolumn{2}{|c|}{ Caballeros (Y) } & \multicolumn{2}{|c|}{ Mancaneota (Z) } & \multicolumn{2}{|c|}{ Pichuycocha (AA) } \\
\hline Year & $\begin{array}{l}\text { Mean } \\
(\mathrm{m})\end{array}$ & $\begin{array}{l}\text { Standard } \\
\text { Deviation } \\
(\mathrm{m})\end{array}$ & $\begin{array}{l}\text { Mean } \\
(\mathrm{m})\end{array}$ & $\begin{array}{l}\text { Standard } \\
\text { Deviation } \\
\text { (m) }\end{array}$ & $\begin{array}{l}\text { Mean } \\
(\mathrm{m})\end{array}$ & $\begin{array}{l}\text { Standard } \\
\text { Deviation } \\
\text { (m) }\end{array}$ & $\begin{array}{l}\text { Mean } \\
(\mathrm{m})\end{array}$ & $\begin{array}{l}\text { Standard } \\
\text { Deviation } \\
(\mathrm{m})\end{array}$ & $\begin{array}{l}\text { Mean } \\
(\mathrm{m})\end{array}$ & $\begin{array}{l}\text { Standard } \\
\text { Deviation } \\
(\mathrm{m})\end{array}$ & $\begin{array}{l}\text { Mean } \\
(\mathrm{m})\end{array}$ & $\begin{array}{l}\text { Standard } \\
\text { Deviation } \\
\text { (m) }\end{array}$ & $\begin{array}{l}\text { Mean } \\
(\mathrm{m})\end{array}$ & $\begin{array}{l}\text { Standard } \\
\text { Deviation } \\
\text { (m) }\end{array}$ \\
\hline 1986 & NA & NA & 4743 & 5 & 4853 & 24 & 4763 & 19 & 5135 & 6 & 5014 & 32 & 5117 & 31 \\
\hline 1989 & NA & NA & 4799 & 8 & 4921 & 65 & 4800 & 15 & 5130 & 12 & 5008 & 15 & 5111 & 20 \\
\hline 1997 & 5088 & 64 & 4840 & 25 & 4913 & 55 & 4911 & 22 & NA & NA & 5151 & 23 & 5173 & 71 \\
\hline 1999 & 5112 & 88 & 4916 & 7 & 5038 & 23 & 4952 & 30 & 5132 & 1 & 5123 & 23 & 5188 & 54 \\
\hline 2002 & 5180 & 38 & 4929 & 16 & NA & NA & 4948 & 42 & 5135 & 6 & 5133 & 28 & 5196 & 60 \\
\hline \multirow[t]{2}{*}{ Mean } & 5127 & 38 & 4845 & 6 & 4931 & 23 & 4875 & 12 & 5133 & 4 & 5086 & 11 & 5157 & 23 \\
\hline & \multicolumn{2}{|c|}{ Santa Rosa (BB) } & \multicolumn{2}{|c|}{ Condorsenja (CC) } & \multicolumn{2}{|c|}{ Yanco (DD) } & \multicolumn{2}{|c|}{ Caballococha (EE) } & \multicolumn{2}{|c|}{ Mean SLA } & & & & \\
\hline Year & $\begin{array}{l}\text { Mean } \\
(\mathrm{m})\end{array}$ & $\begin{array}{l}\text { Standard } \\
\text { Deviation } \\
(\mathrm{m})\end{array}$ & $\begin{array}{l}\text { Mean } \\
(\mathrm{m})\end{array}$ & $\begin{array}{l}\text { Standard } \\
\text { Deviation } \\
(\mathrm{m})\end{array}$ & $\begin{array}{l}\text { Mean } \\
(\mathrm{m})\end{array}$ & $\begin{array}{l}\text { Standard } \\
\text { Deviation } \\
\text { (m) }\end{array}$ & $\begin{array}{l}\text { Mean } \\
(\mathrm{m})\end{array}$ & $\begin{array}{l}\text { Standard } \\
\text { Deviation } \\
(\mathrm{m})\end{array}$ & $\begin{array}{l}\text { Mean } \\
(\mathrm{m})\end{array}$ & $\begin{array}{l}\text { Standard } \\
\text { Deviation } \\
(\mathrm{m})\end{array}$ & & & & \\
\hline 1986 & 4985 & 57 & 5067 & 15 & 4911 & 30 & 4802 & 26 & 4947 & 7 & & & & \\
\hline 1989 & 4942 & 29 & 5076 & 10 & 4908 & 17 & 4875 & 41 & 4976 & 7 & & & & \\
\hline 1997 & 4963 & 68 & 5074 & 6 & 4974 & 40 & 4895 & 26 & 5014 & 10 & & & & \\
\hline 1999 & 5027 & 31 & 5076 & 1 & 4939 & 14 & 4880 & 33 & 5033 & 8 & & & & \\
\hline 2002 & 5063 & 42 & 5077 & 0 & 4938 & 15 & 4898 & 30 & 5044 & 8 & & & & \\
\hline Mean & 4996 & 21 & 5074 & 4 & 4934 & 11 & 4870 & 14 & 5006 & 4 & & & & \\
\hline
\end{tabular}

Raura exhibited comparable ranges, extending from $4743 \pm$ $5 \mathrm{~m}$ a.s.l. (Viconga (V), 1986) to $5196 \pm 60 \mathrm{~m}$ a.s.l. (Pichuycocha (AA), 2002) (Table 4). The mean SLAs ranged from $5033 \pm 23 \mathrm{~m}$ a.s.l. (1989) to $5086 \pm 33 \mathrm{~m}$ a.s.l. (2005) for the Cordillera Huayhuash and from $4947 \pm 7$ ma.s.l. (1986) to $5044 \pm 8$ m a.s.l. (2002) for the Cordillera Raura.

We looked at annual SLAs for individual glaciers as well as mean SLAs and the standard deviations for each range (Tables 3 and 4). The standard deviations for the mean SLA for the Cordillera Huayhuash were larger than those for the Cordillera Raura primarily due to the presence of several glaciers with widths $>1-\mathrm{km}$ in the Cordillera Huayhuash. The larger individual standard deviations for these "wide" glaciers strongly influenced the standard deviation for the mean SLA, calculated as the square root of the sum of the variances for the individual glaciers divided by the number of glaciers included in the mean calculation. For the purpose of the statistical calculations used to derive SLA means and standard deviations, SLAs for individual glaciers were assumed independent. In order to determine statistical signifi- cance of SLA differences, a normal distribution was assumed for all SLAs. Although this assumption may be invalid when sample size is quite small $(n<5)$, the assumption was necessary to perform the 2-sample t-tests used in this study.

\subsection{Glaciers of the Cordillera Huayhuash}

Snowlines for the Cordillera Huayhuash were mapped for each glacier labeled in Fig. 2. Snowline locations for the Cordillera Huayhuash are displayed as overlays on an 45 August 1997 Landsat TM band-3 mosaic in Supplement Fig. S1. Due to the large variability in individual SLAs, the mean SLA was used to characterize the prevailing behavior of the range. Overall, the mean SLA for the Cordillera Huayhuash rose from $5062 \pm 36$ ma.s.l. in 1986 to $5086 \pm$ $33 \mathrm{~m}$ a.s.l. in 2005. Although the SLA rise was not statistically significant at the $95 \%$ confidence level $(P=0.076)$, the relatively small $\mathrm{P}$-value indicates that the rise was fairly unlikely to be a product of random natural variability alone. 

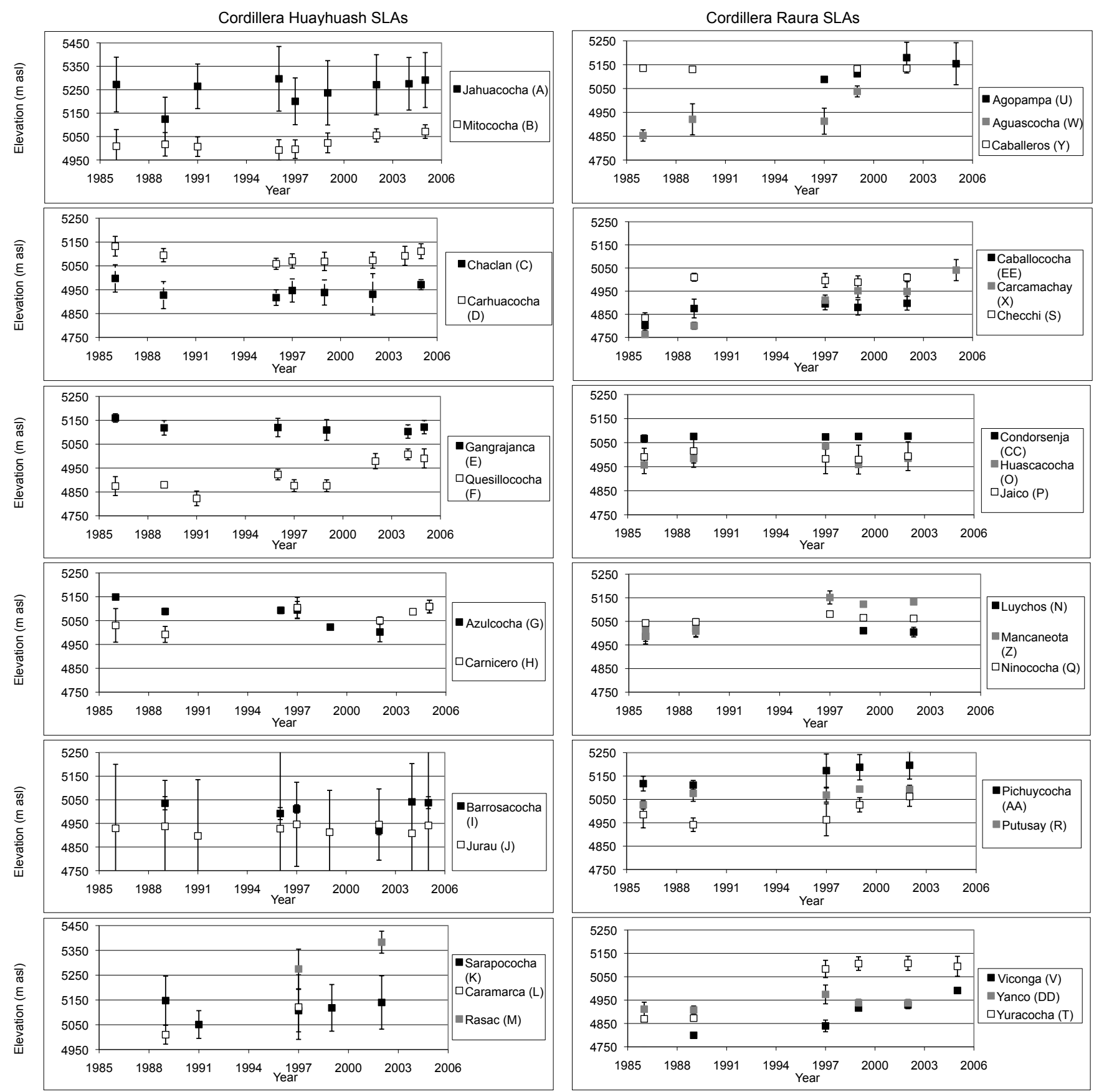

Fig. 3. Mean SLAs for each glacier for the Cordillera Huayhuash and Cordillera Raura. The error bars represent \pm one standard deviation from the mean. All y-axes have the same range $(500 \mathrm{~m})$ although the altitudes vary. See Tables 3 and 4 for the values for each glacier.

Analysis of the mean and individual SLAs indicated that some of the thirteen glaciers in the Cordillera Huayhuash provided more reliable SLAs than others; calculated SLAs were most reliable in valleys that were not avalanche-fed and where SLAs could be measured in almost all Landsat images throughout the time series. The Sarapococha (K), Caramarca $(\mathrm{L})$, and Rasac (M) glaciers may have provided unreliable data due to shadow obscuring their snowlines in several im- ages. Gangrajanca (E) glacier may also have provided unreliable data for several years due to recent avalanches, although no ground-truth data supported the presence of frequent avalanches. With these considerations in mind, eleven of thirteen glaciers with the most complete time series were used to create a comprehensive mean SLA (as described in Sect. 2.5) and to analyze the spatial distribution of modern SLA change throughout the Cordillera Huayhuash. 
SLA and temporal change in SLA ( $\triangle$ SLA) variations from glacier-to-glacier reflected unique accumulation and ablation conditions of individual valleys, as indicated by the SLA variability shown in Fig. 3. Plots of the Cordillera Huayhuash and Cordillera Raura SLAs in Fig. 3 were arranged alphabetically according to glacier IDs (Fig. 2, Tables 3 and 4, respectively) for consistency with the rest of the text.

We compared the mean SLAs to Jahuacocha (A) and Chaclan $(\mathrm{C})$ glaciers $\left(10^{\circ} 14.5^{\prime} \mathrm{S}\right)$ in the Cordillera Huayhuash as a case-study of inter-annual variability across the ridge. These glaciers were specifically selected because Jahuacocha glacier had the largest inter-annual variability and second largest SLA elevation range (i.e. standard deviation) of all glaciers in the Cordillera Huayhuash, making it an interesting example of end-member behavior. The $\triangle$ SLA of Jahuacocha glacier from 1986 to 2005 was indiscernible due to its large standard deviation; however, the SLA change from $5124 \pm 94$ m a.s.l. to $5297 \pm 138 \mathrm{~m}$ a.s.l. from 1989-1996 may indicate positive, although not statistically significant, $\triangle$ SLA during this time period. When this value was compared to the contemporaneous $\Delta$ SLA of $-10 \mathrm{~m}(4927 \pm 57 \mathrm{~m}$ a.s.l. to $4917 \pm 33 \mathrm{~m}$ a.s.l.) for Chaclan glacier, no relationship between inter-annual SLAs was evident. Differences between the SLAs of these glaciers may have been due to their locations on opposite sides of the ridge or other microclimate factors. Additionally, the inter-annual SLA variability demonstrated for these glaciers was not ubiquitous, as shown in Fig. 4, emphasizing the need to examine changes in the mean SLA for the entire range rather than considering a few select glaciers as regional archetypes.

Klein and Isacks (1998) mapped a strong east-west SLA difference from 1984 to 1987 across the eastern ridge of the Andes Mountains in southern Peru using remote sensing techniques similar to those described above. Their data described the eastern branch of the Andean Cordillera, however, the trend of lower eastern and higher western SLAs should exist in the Cordillera Huayhuash due to the similar easterly source of precipitation (e.g. Kaser and Osmaston, 2002; Bookhagen and Strecker, 2008). Mean SLAs in the Cordillera Huayhuash were $5050 \pm 19 \mathrm{~m}$ a.s.l. (5100 $\pm 148 \mathrm{~m}$ a.s.l.) in 1986 and $5015 \pm 19 \mathrm{~m}$ a.s.l. (5069 \pm $57 \mathrm{~m}$ a.s.l.) in 2002 for the eastern (western) side of the ridge. The difference across the ridge was not statistically significant in $1986(P=0.358)$ or in $2002(P=0.082)$. Similarly, the difference across the ridge was not statistically significant in $2005(P=0.183)$ when the mean SLAs for the eastern and western sides were $5069 \pm 11 \mathrm{ma}$ a.s.l. and $5116 \pm 88 \mathrm{~m}$ a.s.l., respectively. The lack of statistical significance for the difference between the eastern and western SLAs in the Cordillera Huayhuash was most likely due to the large standard deviation associated with the western mean SLA from the influence of the large standard deviation of Jurau (J) glacier (Fig. 4) and the relatively small mean SLA difference $(\sim 50 \mathrm{~m})$ across the ridge.
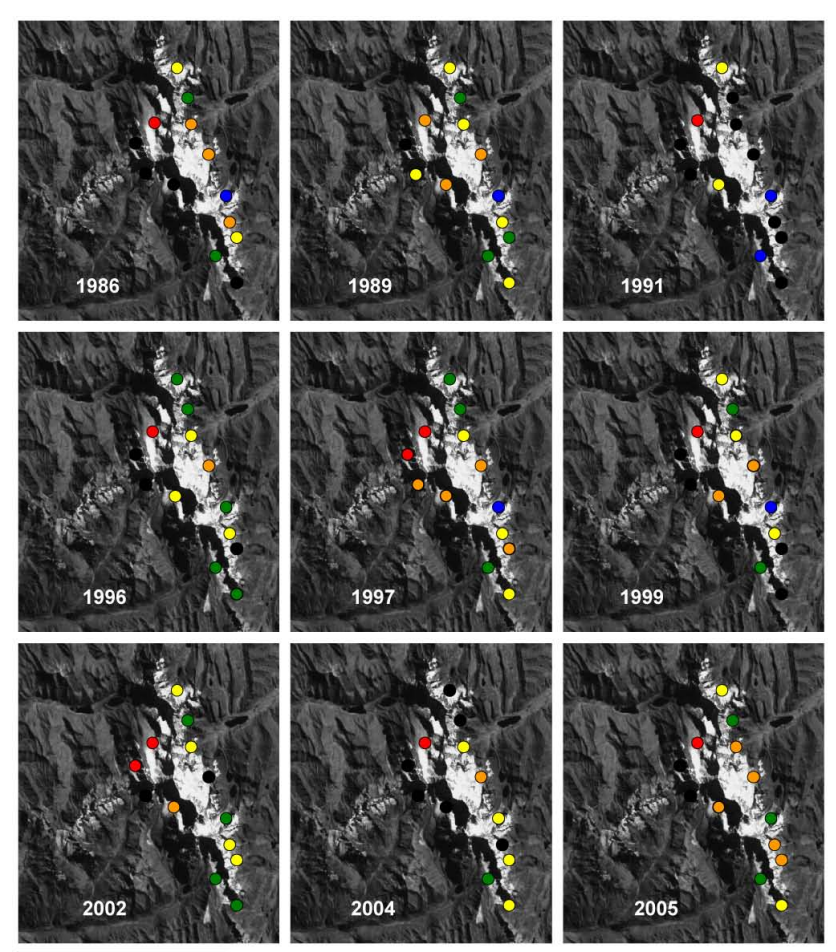

Fig. 4. Time series of the Cordillera Huayhuash SLAs from 19862005. Data gaps represented by black circles are primarily attributed to shadow or poor snow-ice differentiation. Glaciers on the western side of the ridge typically have higher SLAs than those on the eastern side. Little annual change can be distinguished in several images due to large elevation categories.

Although the mean SLA was lower on the eastern side of the ridge in the Cordillera Huayhuash, only half of the glaciers on the eastern side had SLAs lower than the mean for the range during the study period. The differences between glacier SLAs are not easily explained, though there were two distinct groups. One of the groups was in the northeast part of the range and the other was in the southern part of the range spanning the east and west sides of the ridge (Fig. 2). One possibility is that different valley orientations with respect to high mountain peaks channeled moist air into the lower SLA valleys and deflected moist air from the higher SLA valleys. Although this hypothesis could explain the lower SLA trends, the exact mechanisms causing the air movement were not clear.

In addition to the east-west differences in the mean SLA noted above, all glaciers with falling SLAs throughout the study period (Chaclan - C, Carhuacocha - D, Gangrajanca - E, and Azulcocha - G) were located on the eastern side 

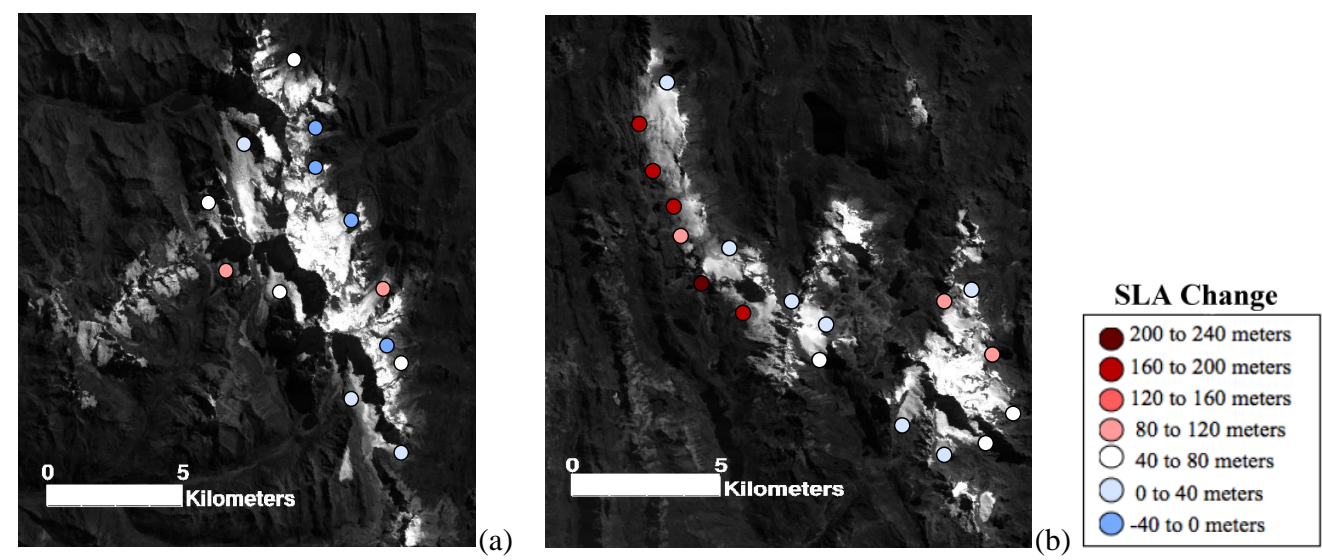

Fig. 5. SLA change from 1986-2005 in the Cordillera Huayhuash (a) and from 1986 to 2002 for the Cordillera Raura (b). If SLA data were unavailable for 1986 and/or 2005 for the Cordillera Huayhuash or for 1986 and/or 2002 for the Cordillera Raura, data from the closest year with available data were used to calculate SLA change. The $\triangle$ SLA values for individual glaciers are shown as colored circles, with dark red circles indicating the largest SLA rise and darker blue circles indicating SLAs that fell. Calculation of $\triangle$ SLAs excludes consideration of SLA standard deviations.

of the range (Fig. 5a). Although four glaciers with falling SLAs were located on the eastern side of the range, glaciers with significant SLA rises $(>70 \mathrm{~m})$ were also found on the eastern side, generating questions regarding why SLAs were so highly variable for nearby glaciers. We investigated the possibility of unreliable images to determine the validity of all measurements and found that although abnormally low SLAs could have been attributed to recent high elevation snow events, the elimination of images with signs of recent snowfall minimized the effects of snow events on our analysis.

\subsection{Glaciers of the Cordillera Raura}

SLAs from the Cordillera Raura provided an additional proxy for regional climate variability in the central Andes, with presumably comparable climatological conditions relative to the neighboring Cordillera Huayhuash. Eighteen glaciers in the Cordillera Raura were observed from 1986 to 2005 with satellite images from $6 \mathrm{yr}$ during the study period. Snowline locations for the Cordillera Raura are displayed as overlays on an 4-5 August 1997 Landsat TM band-3 mosaic in Supplement Fig. S2. Statistics calculated for this range excluded data from 2005, due to the failure in the scan line corrector of the Landsat satellite in 2003, which resulted in large gaps in spatial coverage over many glaciers in the Cordillera Raura.

The mean SLA for the Cordillera Raura rose from $4947 \pm$ $7 \mathrm{~m}$ a.s.l. to $5044 \pm 8 \mathrm{~m}$ a.s.l. from 1986 to 2002 .The mean SLA rise was statistically significant at the $95 \%$ confidence level $(P<0.001)$, indicating that the SLA rise was large enough that we can confidently say it reflected real SLA change rather than random variability, in the absence of the other error sources not included in our standard deviations. Although data were more limited for the Cordillera Raura than the Cordillera Huayhuash (5 dates from 1986-2002), the time series provided a fairly consistent data set for individual glaciers. The most important temporal trend derived from the Cordillera Raura was the rising SLAs on all glaciers throughout the range (Fig. 3). Individual glaciers' $\triangle$ SLAs range from negligible change on Caballeros (Y) glacier to $+236 \mathrm{~m}$ on Yuracocha (T) glacier (Fig. 5b), with a mean $\triangle$ SLA of +97 m from 1986 to 2002.

Spatial variability throughout the Cordillera Raura demonstrated an east-west contrast in SLA trends that differed from the Cordillera Huayhuash, as shown in the SLA time series for the Cordillera Raura (Fig. 6). On average, SLAs from glaciers on the western side of the ridge had lower SLAs than those on the eastern side; in contrast to the Cordillera Huayhuash, which had lower SLAs on the eastern side of the ridge. The east-west difference, largest in 1986, decreased in magnitude during the study period due to a more rapid SLA rise on the western side of the ridge. In 1986, the western SLAs (Fig. 2) were located at a mean elevation of $4878 \pm 10 \mathrm{~m}$ a.s.l. and eastern SLAs were located at a mean of $5008 \pm 9 \mathrm{~m}$ a.s.l. In 2002, the SLAs were located at mean elevations of $5031 \pm 9 \mathrm{~m}$ a.s.l. and $5055 \pm 11 \mathrm{~m}$ a.s.l., respectively. The difference between the eastern and western SLAs was statistically significant at the $95 \%$ confidence level for $1986(P<0.001)$ and for $2002(P<0.001)$. The results of the t-test suggest that although the difference between eastern and western SLAs decreased with time, the difference did not become small enough to be attributed to random variability alone, excluding other possible sources of error not included in our calculated means and standard deviations.

\section{Discussion and conclusions}

SLAs in the Cordilleras Huayhuash and Raura were temporally and spatially variable, as shown in Table 5. From 1986 

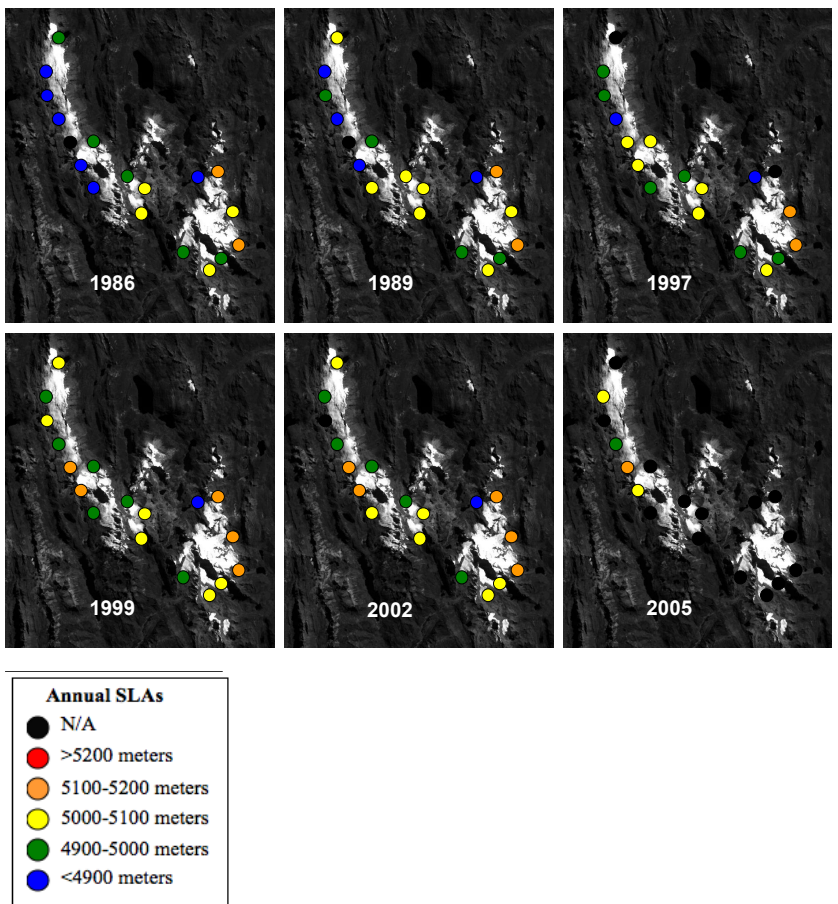

Fig. 6. Time series of the Cordillera Raura SLAs from 1986-2005. Data gaps represented by black circles are due to shadow or poor snow-ice differentiation. Glaciers on the western side of the ridge typically have lower SLAs than those on the eastern side. Little annual change can be distinguished in several images due to large elevation categories.

to 2005, the mean SLA in the Cordillera Huayhuash was stable (a statistically insignificant rise from $5062 \pm 36 \mathrm{~m}$ a.s.1. to $5086 \pm 35 \mathrm{~m}$ a.s.1. was observed). In the Cordillera Raura, the mean SLA rose from $4947 \pm 7 \mathrm{~m}$ a.s.l. to $5044 \pm 8 \mathrm{~m}$ a.s.1. from 1986 to 2002. Modern SLAs in southern Peru have been documented near $5200 \mathrm{~m}$ (Mark et al., 2002; Dornbusch, 1998), and the lower SLAs documented here may be attributed to topographic and/or climatic differences between the regions.

A simple comparison of SLAs between the Cordillera Huayhuash and the Cordillera Raura displays multiple similarities as well as noticeable differences between the two ranges. Although the ranges are located in close proximity, their recent SLA histories are quite different. As shown in Fig. 7, the mean SLAs from 1986 were much lower in the Cordillera Raura $(4947 \mathrm{~m})$ than the Cordillera Huayhuash (5062 m). The SLAs in the Cordillera Raura, however, showed a steadier, significant rise from 1986 to 2002 than those of the Cordillera Huayhuash, which were much more variable with no statistically significant trends. In 2002 the Cordillera Raura had a mean SLA of $5044 \pm 8 \mathrm{~m}$ a.s.1. and the Cordillera Huayhuash had a mean SLA of $5037 \pm 25 \mathrm{~m}$ a.s.l.

Other interesting spatial characteristics arise when comparing the two ranges. Overall, the SLAs on the eastern side
Table 5. Summary of mean, standard deviation, $\Delta$-value, and linear trend for individual glacier SLAs. The solid horizontal line distinguishes Cordillera Huayhuash glaciers (top) from those in the Cordillera Raura.

\begin{tabular}{|c|c|c|c|c|c|}
\hline Glacier & $\begin{array}{c}\text { Mean } \\
\text { (ma.s.1.) }\end{array}$ & $\begin{array}{l}\text { SD } \\
(\mathrm{m})\end{array}$ & $\begin{array}{r}\Delta \text { SLA } \\
1986-2005^{\mathrm{a}}\end{array}$ & $\begin{array}{r}\text { Linear Trend } \\
\qquad\left(\mathrm{m} \mathrm{a}^{-1}\right)\end{array}$ & $R^{2 \mathrm{~b}}$ \\
\hline Azulcocha (G) & 5080 & 9.2 & -40 & -4.0 & 0.29 \\
\hline Barrosacocha (I) & 5006 & 8.7 & 2.4 & -8.2 & 0.86 \\
\hline Caramarca (L) & 5066 & 67.7 & $111(+)$ & 13.9 & 1 \\
\hline Carhuacocha (D) & 5090 & 11.9 & -21 & -1.2 & 0.12 \\
\hline Carnicero (H) & 5062 & 15.9 & $79(+)$ & 4.3 & 0.57 \\
\hline Chaclan (C) & 4947 & 20.6 & -26.2 & -1.0 & 0.06 \\
\hline Gangrajanca (E) & 5123 & 14.5 & $-38.4(+)$ & -1.8 & 0.49 \\
\hline Jahuacocha (A) & 5248 & 38.8 & 19 & 3.3 & 0.17 \\
\hline Jurau $(\mathrm{J})$ & 4927 & 85.2 & 12 & 0.32 & 0.02 \\
\hline Mitococha (B) & 5021 & 15.9 & $62.2(+)$ & 2.9 & 0.45 \\
\hline Quesillococha (F) & 4914 & 9.6 & $116(+)$ & 7.6 & 0.64 \\
\hline Rasac (M) & 5434 & 45.7 & $79.2(+)$ & 15.8 & 1 \\
\hline Sarapococha $(\mathrm{K})$ & 5119 & 42.5 & -7.5 & 4.7 & 0.32 \\
\hline Agopampa (U) & 5134 & 29.6 & $72.2(+)$ & 9.6 & 0.67 \\
\hline Aguascocha(W) & 4932 & 22.8 & $185.6(+)$ & 9.9 & 0.64 \\
\hline Caballeros(Y) & 5133 & 3.0 & -1.8 & 0.02 & 0.006 \\
\hline Caballococha (EE) & 4870 & 14.1 & $95.1(+)$ & 4.7 & 0.66 \\
\hline Carcamachay (X) & 4903 & 12.7 & $278.9(+)$ & 13.7 & 0.97 \\
\hline Checchi (S) & 4968 & 10.5 & $151.3(+)$ & 7.4 & 0.45 \\
\hline Condorsenja (CC) & 5074 & 3.8 & $7.7(+)$ & 0.43 & 0.54 \\
\hline Huascacocha $(\mathrm{O})$ & 4984 & 9.0 & $25(+)$ & 1.4 & 0.084 \\
\hline Jaico (P) & 4992 & 26.0 & 5.6 & -1.0 & 0.23 \\
\hline Luychos (N) & 5005 & 13.1 & $17.2(+)$ & 0.56 & 0.1 \\
\hline Mancaneota (Z) & 5086 & 11.1 & $135.2(+)$ & 9.2 & 0.84 \\
\hline Ninococha (Q) & 5060 & 6.7 & 2.6 & 1.7 & 0.55 \\
\hline Pichuycocha (AA) & 5157 & 22.7 & $75.7(+)$ & 5.7 & 0.95 \\
\hline Putusay (R ) & 5072 & 10.7 & $65.5(+)$ & 3.3 & 0.67 \\
\hline Santa Rosa (BB) & 4996 & 21.4 & $81.1(+)$ & 5.1 & 0.51 \\
\hline Viconga (V) & 4870 & 5.4 & $248.8(+)$ & 12.1 & 0.94 \\
\hline Yanco (DD) & 4934 & 11.4 & 8 & 2.6 & 0.45 \\
\hline Yuracocha $(\mathrm{T})$ & 5022 & 11.8 & $235.9(+)$ & 14.7 & 0.86 \\
\hline
\end{tabular}

Note: glacier names are based on major lakes in the valley or nearby peaks. Names do not necessarily reflect official geographic names. Refer to Fig. 2 for approximate locations. Annual SLAs are reported in Tables 3 and 4 and Fig. 4.

a $\triangle$ SLAs significant at the $95 \%$ confidence level are in bold with a (+) behind the

value.

of the ridge were lower than the mean SLA in the Cordillera Huayhuash but higher than the mean SLAs in the Cordillera Raura. However, eastern SLAs in both ranges rose at a slower rate than their respective western SLAs and, in general, the Cordillera Huayhuash SLAs rose at a slower rate on average than those in the Cordillera Raura. The east-west differences in both ranges are illustrated in Fig. 5a and b. Similar east-west differences noted in the Cordillera Blanca by Kaser et al. (1996) and Kaser and Georges (1997), were only partly accounted for by temperature change throughout the region. Kaser et al. (1996) concluded that SLA variability was half-explained by temperature change and Kaser and Georges (1997) stated that changes in humidity, precipitation, and cloud cover were more important than temperature change as controls of SLA position. The opposing patterns observed for these ranges, therefore, were not easily explained and may indicate multiple controls of SLA position such as valley orientation, microclimate, hypsometry, and 


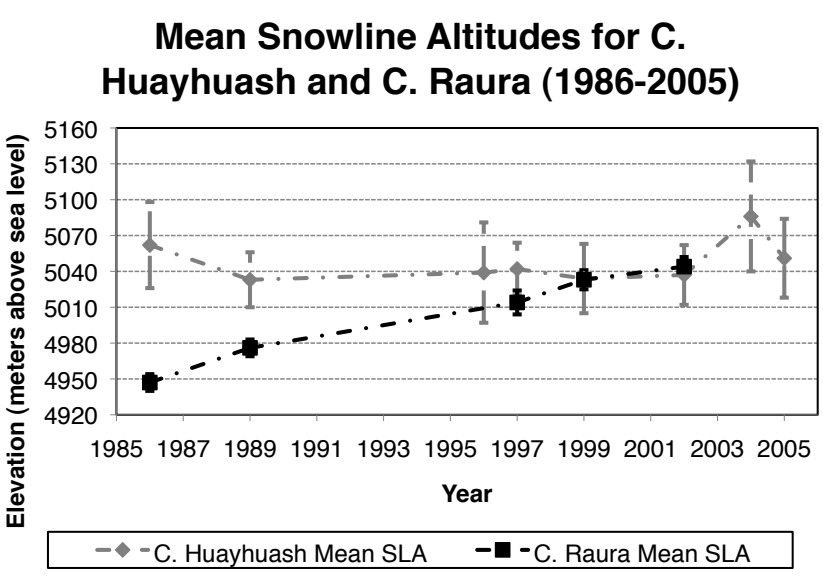

Fig. 7. Comparison of the average SLAs calculated for the Cordillera Huayhuash and Cordillera Raura. Means and standard deviations are calculated as described in the text. Error bars indicate \pm 1 standard deviation.

catchment area in addition to regional temperature change and variability.

Despite possible microclimate difference across the ridge that may have caused the observed east-west SLA variability, mean SLAs were used to represent the prevalent trends in the Cordilleras Huayhuash and Raura, assuming the influence of microclimate on annual individual SLA position is random and thus reduced when calculating the mean for the range. A statistically significant rise in the Cordillera Raura mean SLA and an observed, but not statistically significant rise in the Cordillera Huayhuash mean SLA, may indicate a shift toward a warmer and drier climate in the central Peruvian Andes. In general, SLA change is best explained by either decreased accumulation in the wet season or increased ablation during the dry season, or both factors combined. Annual precipitation changes have, however, little effect on SLAs in the inner tropics relative to variations in air temperature (Francou et al., 2004; Kaser and Osmaston, 2002). Also, since the dispersion coefficient indicating annual variations in precipitation is $14 \%$ in the Peruvian Andes (Schwerdtfeger, 1976), suggesting (on average) little precipitation change over the 20 -yr study period, we assumed moisture variation was not likely to be the primary cause of shortterm SLA variability. Furthermore, temperature in the tropical Andes is strongly correlated to humidity, cloudiness, and precipitation (Vuille et al., 2008), indicating that variations in temperature strongly influence SLAs through a variety of meteorological variables.

If we assume that moisture variations are not a major influence on temporal trends in SLA position, and an average lapse rate of $-0.6^{\circ} \mathrm{C}$ per $100 \mathrm{~m}$ is applicable, the change in temperature $(\Delta T)$ from 1986 to 2005 in the Cordillera Huayhuash ranged from $+0.01^{\circ} \mathrm{C}$ to $+0.7^{\circ} \mathrm{C}$, equivalent to an average of $+0.2^{\circ} \mathrm{C} /$ decade. These $\Delta T$ estimates were derived from individual maximum and minimum SLA changes in glaciers with rising SLAs from 1986 to 2005 in the Cordillera
Huayhuash. When similar analysis was made in regard to the Cordillera Raura, the $\Delta T$ from 1986 to 2005 was $+0.02^{\circ} \mathrm{C}$ to $+1.4^{\circ} \mathrm{C}$, equivalent to an average of $+0.36^{\circ} \mathrm{C} /$ decade. When falling SLAs were included in temperature change calculations, the $\Delta T$ for the two ranges combined varied from $-0.25^{\circ} \mathrm{C}$ to $+1.4{ }^{\circ} \mathrm{C}$, an average of $0.58^{\circ} \mathrm{C} /$ decade.

Data analyzed by Vuille and Bradley (2000) provided recent temperature change estimates of $+0.09^{\circ} \mathrm{C} /$ decade to $+0.16^{\circ} \mathrm{C} /$ decade in the Andes Mountains. Temperature changes were derived from regional climate data collected between $4000 \mathrm{~m}$ a.s.l. and $5000 \mathrm{~m}$ a.s.l., providing a fairly accurate base assessment of the temperature change inferred by the rising SLAs in the Cordilleras Huayhuash and Raura. Their $\Delta T$ values averaged $+0.11^{\circ} \mathrm{C} /$ decade from $1939-1998$ with a significant increase to $+0.34^{\circ} \mathrm{C} /$ decade from $1973-$ 1998 in the Tropical Andes. The linear temperature increase suggested by Vuille and Bradley (2000) may partially explain the contemporaneous linear SLA rise in the Cordillera Raura, illustrated in Fig. 7. Changes in the Cordillera Huayhuash's SLAs were variable throughout the study period and could not be explained by a linear temperature increase alone.

Annual data from Huaraz, Peru located at $9^{\circ} 31^{\prime} 36.91^{\prime \prime} \mathrm{S}$, $77^{\circ} 31^{\prime} 37.35^{\prime \prime} \mathrm{W}$ on the western, drier side of the range (slightly to the SW of the main branch of the Cordillera Blanca) support our previous assumption that moisture variations throughout the study period did not significantly change SLAs, assuming precipitation totals for Huaraz (3090 m a.s.l.) represent regional precipitation patterns for the local cordilleras. A similar rate of SLA rise between the Cordilleras Huayhuash and Blanca (e.g. Mark and Seltzer, 2005) in the recent past suggests these regions were subjected to comparable precipitation variations, which were presumably represented by the Huaraz weather station data. A weak tendency toward increased precipitation was recorded for this region (Vuille et al., 2003, 2008), further suggesting observed precipitation change should not be responsible for observed SLA change.

The comparison between our $\Delta T$ estimates from SLAs in the Cordilleras Huayhuash and Raura with $\Delta T$ values from other sources suggests that temperature change is the primary control of SLA position and that the methods employed in this study provided reasonable SLA estimates. If our assumptions and subsequent conclusions are valid, the data suggest that the zero degree isotherm in this region increased to $\sim 5040 \mathrm{~m}$ a.s.l., as indicated by the comparable 2002 SLAs in both ranges. SLA variability in the Cordillera Huayhuash was, however, difficult to explain and may have been due to differences in regional weather variability relative to the Cordillera Raura. Spatial and temporal variations in the Cordillera Huayhuash SLAs, also suggested that hypsometry, humidity, shading, and microclimate affected interannual SLAs. Despite inter-annual differences between the ranges, the comparable SLAs in both ranges since the late 1990 's may reflect long-term temperature change throughout the central Peruvian Andes. 
The tropical impacts are already well known to those who depend on high elevation glaciers for water for consumption, agriculture, and hydroelectric power, because $80 \%$ of the water resources on the Pacific side of Peru originate from the snow and ice in the Andes (Coudrain et al., 2005). Overall, the glacial change indicated by the rising SLAs in Cordillera Raura since 1986 may indicate a temperature increase in tropical regions. If the SLA rises are close to the upper estimate for the Cordillera Raura and our temperature calculations are valid, the associated temperature increase of $1.4^{\circ} \mathrm{C}$ over $20 \mathrm{yr}$ should have noticeable implications for glacier change, melt water availability and seasonality, and water resources for local communities.

\section{Supplementary material related to this article is available online at: http://www.the-cryosphere.net/5/419/2011/ tc-5-419-2011-supplement.pdf.}

Acknowledgements. We thank NASA for its financial support for this research as well as Lehigh University for the computer infrastructure used for data analysis. Funding for research was provided by the NASA New Investigator Program (Grant NNG04GO95G to J. Ramage) and was used to support the work and the purchase of NASA/USGS data. We would also like to thank the Global Land Cover Facility (GLCF) at the University of Maryland and EROS Data Center-NASA/USGS for the use of available satellite imagery in such a remote region of the world. We thank B. Mark, J. Galster, G. Bippus, H. de Angelis, M. Pelto, and A. Rabatel for their constructive comments used to improve the paper, M. Vuille for providing data prior to publication, and E. Kaizar for help with the use of statistics.

Edited by: G. H. Gudmundsson

\section{References}

Andrews, J.: Glacial Systems: An approach to glaciers and their environments, North Scituate, MA, Duxbury Press, 191 pp., 1975.

Bliss, N. B. and Olsen, L. M.: Development of a 30-arc-second digital elevation model of South America, Pecora Thirteen, Human Interactions with the Environment-Perspectives from Space, Sioux Falls, South Dakota, 20-22 August 1996.

Bookhagen, B. and Strecker, M.: Orographic barriers, highresolution TRMM rainfall, and relief variations along the eastern Andes, Geophys. Res. Lett., 35, L06403, doi:10.1029/2007GL032011, 2008.

Bradley, R., Vuille, M., Diaz, H., and Vergara, W.: Threats to water supplies in the tropical Andes, Science, 312, 1755-1756, doi:10.1126/science.1128087, 2006.

Chander, G. and Markham, B.: Revised Landsat-5 TM radiometric calibration procedures and postcalibration dynamic ranges, IEEE T. Geosci. Remote, 24, 2674-2677, 2003.

Coudrain, A., Francou, B., and Kundzewicz, Z. W.: Glacier shrinkage in the Andes and consequences for water resources, Hydrolog. Sci. J., 50, 925-932, 2005.
De Angelis, H., Rau, F., and Skvarca, P.: Snow zonation on Hielo Patagónico Sur, Southern Patagonia, derived from Landsat 5 TM data, Global Planet. Change, 59, 149-158, 2007.

Dornbusch, U.: Current large scale climatic conditions in south Peru and their influence on snowline altitudes, Erdkunde, 52, 4154, 1998.

Farr, T. G. and Kobrick, M.: Shuttle Radar Topography Mission produces a wealth of data, EOS Trans. AGU, 81, 583-585, 2000.

Francou, B., Vuille, M., Favier, V., and Caceres, B.: New evidence for an ENSO impact on low-latitude glaciers; Antizana 15, Andes of Ecuador, 0 degrees 28' S, J. Geophys. Res., 109, D18106, doi:10.1029/2003JD004484, 2004.

Kaser, G. and Georges, C.: Changes of the equilibrium-line altitude in the tropical Cordillera Blanca, Peru, 1930-1950, and their spatial variations, Ann. Glaciol., 24, 344-349, 1997.

Kaser, G. and Osmaston, H.: Tropical glaciers, Cambridge, Cambridge University Press, 47-207, 2002.

Kaser, G., Georges, C., and Ames, A.: Modern glacier fluctuations in the Huascaran-Chopicalqui-Massif of the Cordillera Blanca, Peru, Zeitschrift fuer Gletscherkunde und Glazialgeologie, 32, 91-99, 1996.

Kaser, G., Juen, I., Georges, C., Gomez, J. and Tamayo, W.: The impact of glaciers on the runoff and the reconstruction of mass balance history from hydrological data in the tropical Cordillera Blanca, Peru, J. Hydrol., 282, 130-144, doi:10.1016/S00221694(03)00259-2, 2003.

Klein, A. and Isacks, B.: Alpine glacial geomorphological studies in the central Andes using Landsat Thematic Mapper images, Glacial Geology and Geomorphology, rp01/1998, 1998.

Mark, B., Seltzer, G., Rodbell, D., and Goodman, A.: Rates of deglaciation during the last glaciation and Holocene in the Cordillera Vilcanota-Quelccaya Ice Cap region, Southeastern Peru, Quaternary Res., 57, 287-298, 2002.

Mark, B. G.: Hydrochemical evaluation of changing glacier meltwater contribution to stream discharge: Callejon de Huaylas, Peru, Hydrolog. Sci. J., 50, 975-987, 2005.

Mark, B. G. and Seltzer, G. O.: Evaluation of recent glacier recession in the Cordillera Blanca, Peru (AD 1962-1999): spatial distribution of mass loss and climatic forcing, Quaternary Sci. Rev., 24, 2265-2280, 2005.

Morales Arnao, C.: Las Cordilleras del Peru, Universidad de San Martin de Porres: Tarea Asociación Gráfica Educativa, 29-165, 2001.

Schwerdtfeger, W. (Ed.): Climates of Central and South America, World Survey of Climatology, 12, 153-173, 1976.

Vuille, M. and Bradley, R.: Mean annual temperature trends and their vertical structure in the tropical Andes, Geophys. Res. Lett., 27, 3885-3888, 2000.

Vuille, M., Bradley, R., Werner, M., and Keimig, F.: 20th century climate change in the tropical Andes; observations and model results, Climate variability and change in high elevation regions; past, present, and future, Climatic Change, 59, 75-99, 2003.

Vuille, M., Francou, B., Wagnon, P., Juen, I., Kaser, G., Mark, B., and Bradley, R.: Climate change and tropical Andean glaciers: Past, present and future, Earth-Sci. Rev., 89, 79-96, 2008.

Yanahuanca: Hoja 21-j, Carta Nacional 1:100 000 Primera edición, El Instituto Geográfico Nacional, Lima, Peru 1969-1970, 2002. 